Volume 1, Number 1 (2021)

\title{
Veloziferisch (Velociferian)
}

\section{BRYAN NORTON}

To cite this article: Norton, Bryan. "Veloziferisch (Velociferian)." Goethe-Lexicon of Philosophical Concepts 1 , no. 1 (2021): 113-120

To link to this article: https://doi.org/10.5195/glpc.2021.25

Published by the University Library System, University of Pittsburgh.

\section{(c)}

Entries in this Lexicon are licensed under a Creative Commons Attribution 4.0 United States License.

Copyright $\odot$ the Author(s). 


\section{Veloziferisch (Velociferian)}

The lexeme veloziferisch (velociferian) was first coined by Goethe in an unsent letter from 1825 and entered the public stage four years later with the second edition of the novel Wilhelm Meisters Wanderjahre, oder die Entsagenden (1829; Wilhelm Meister's Journeyman Years, or The Renunciants). As a portmanteau, the neologism, which is composed of the Italian velocità and the German luziferisch, combines two central elements of the Goethean imaginary: the accelerated velocity of modern life and the "luciferian" function of negation. Das Veloziferische marks a dangerous speed at which organic growth is outpaced by the rapid acceleration of technological development. At velociferian speeds, the otherwise figurative role of negation in Goethe's philosophy of nature takes on a disfiguring function, highlighted most clearly by the techno-accelerationist allegory Faust. The invention of this term has prompted recent investigations into the relationship between technological development and social acceleration in modernity. Furthermore, an appreciation of Goethe's critique of the velociferian enables a fuller understanding of his unique position in relation to broader trends in natural philosophy and the philosophy of biology (Spinoza, Schelling, and Erwin Schrödinger), in addition to the philosophy of technology (Thomas Carlyle and Bruno Latour).

\section{Introduction}

The lexeme veloziferisch is a surprisingly heterogenous word that Goethe first coined in an unsent postscript to a letter addressed to the Prussian lawyer Nicolovius in $1825 .^{1}$ The term entered the public stage four years later in 1829 with the release of the second edition of Goethe's novel Wilhelm Meister's Journeyman Years, or the Renunciants. The neologism, composed of the Italian velocità and the German luziferisch, combines two elements that play a central role in the Goethean imaginary: the accelerating velocity of modern life and the figurative work of negation, here hinted at by the luciferian. The term thus casts a critical glance at the rapidly quickening pace of activity that Goethe experienced towards the end of his life. The term veloziferisch marks the transgression of a limit point beyond which the speed of technological and communication systems proves destructive to natural growth and individuation. Yet it also hints at an important flexibility that Goethe imputes to the pace of figuration, a flexibility that possesses not only upper limits but also lower boundaries that deserve to be explored in Goethe's oeuvre.
This article is divided into five main sections, each of which explores a different facet of Goethe's diagnosis of his age as veloziferisch. In the first section, the composition of this portmanteau is discussed in further detail, in addition to the often-overlooked flexibility Goethe affords to the speed of organic figuration, or Bildung. This line of thinking concerning the pace of growth extends into the second section, in which the relationship between speed, negation, and figuration is analyzed in detail. In the third section, Goethe's pronouncements regarding the veloziferisch tendencies of modern life are placed alongside attempts by other philosophers to come to terms with an accelerating rate of technological advancement. In the fourth section, the impact of Goethe's term on more contemporary theoretical writings regarding the speed of modernity is discussed, with particular attention paid to the way in which Goethe's Faust character is often viewed as an embodiment of the manic, destructive ideal of an "erfülltes Leben," a "full life" that is marked by impatience and restlessness. In the fifth and final section, the invocation of a broken rudder in Goethe's play "Torquato Tasso" is introduced as a vital Denkfigur (figure of thought) for navigating Goethe's thinking concerning the speed of modernity and its impact on aesthetic and natural figuration. 


\section{Veloziferisch: The Formation of a Term}

At the end of book two of Wilhelm Meister's Journeyman Years, in the excursus titled "Betrachtungen im Sinne der Wanderer" (Observations in the Mindset of the Wanderers), Goethe decries his age as one which "nichts reif warden läßt" (lets nothing ripen). It is a time of accelerated intensity in which "man im nächsten Augenblick den vorhergehenden verspeist, den Tag im Tage vertut, und so immer aus der Hand in den Mund lebt, ohne irgend etwas vor sich zu bringen" (one lives from hand to mouth, each moment consuming the previous moment, wasting day after day without producing anything lasting). Scathingly, Goethe continues:

Haben wir doch schon Blätter für sämtliche Tageszeiten! ein guter Kopf könnte wohl noch eins und das andere interkalieren. Dadurch wird alles was ein jeder tut, treibt, dichtet, ja was er vor hat, in's öffentliche geschleppt. Niemand darf sich freuen oder leiden als zum Zeitvertrieb der übrigen; und so springt's von Haus zu Haus, von Stadt zu Stadt, von Reich zu Reich, und zuletzt von Weltteil zu Weltteil, alles veloziferisch. (FA 1.10:563)

Do we not already have enough pages for all the daily papers! A good head can surely intercalate one and the other. In this way everything that anybody goes about doing, writing, even what one intends to do in the future, it is all dragged before the public eye. No one can suffer or enjoy themselves for a moment except as a means of mere entertainment for others; and so it springs from house to house, city to city, from domain to domain and ultimately from corner to corner of the globe, everything veloziferisch.

This fragment, a verbatim transcription of Goethe's earlier unsent letter, has caught the critical imagination of a number of theorists who have taken inspiration from the early diagnosis of modernity they find in Goethe's oeuvre. The term is seen as an expression of Goethe's "discovery of slowness," which presents a precursor of sorts to the contemporary interest in "slow thinking" in a number of fields. ${ }^{2}$ Yet, veloziferisch is also a surprisingly plastic and dynamic concept that interfaces with Goethe's lifelong reflection on organic growth and the work of figuration in nature and thought. The construction of the term even presents an imaginative product of figuration itself, as veloziferisch is a portmanteau of the Italian term velocità, signifying speed, and the German luziferisch, that which concerns the devil, Lucifer. The term veloziferisch marks a hurried pace of motion, as we have seen in the fragment from the Wanderjahre, at which point nothing can ripen or reach its full potential. Even more fittingly, Goethe's term suggests a boundary or a limit point for modern growth and technological acceleration. Veloziferisch describes motion at a speed that has surpassed that of Bildung-of organic, healthy motion.

\section{The Speed of Negation: Figuration and Determination in the Philosophy of Nature}

While Goethe would have been hesitant to define or quantify the limit posed on Bildung by das Veloziferische, it is equally important to reflect on the work performed by the "luciferian" element, which in the Goethean imaginary is integrally connected to the dialectical work of negation. In Goethe's Faust, it is the demonic figure Mephistopheles who refers to himself as "der Geist, der stets verneint" (FA 1.7:65; the spirit who constantly negates). While it may be tempting to understand the Faust tragedy as the work of pure negation alone, let us not forget that Faust's fate is tied to his "Ungeduld" (impatience), to his desire to throw himself into the torrents of modern life and forgo his previous existence of scholarly reflection. The Mephistophelean pronouncement linking the luciferian to negation may thus serve as a reminder of the productive, even necessary role of negation in Goethe's writings when it is not coupled with breakneck speeds.

This connection between productivity and luciferian negation is playfully pushed to the allegorical limit in book eight of Goethe's autobiography, Dichtung und Wahrheit (Poetry and Truth) where Goethe discusses the creation of the devil Lucifer as a result of the productive drive's need for incessant cosmological activity:

Ich möchte mir wohl eine Gottheit vorstellen, die sich von Ewigkeit her selbst produziert; da sich aber Produktion nicht ohne Mannigfaltigkeit denken läßt, so mußte sie sich notwendig sogleich als ein Zweites erscheinen, welches wir unter dem Namen des Sohns anerkennen. (FA 1.14:383) 
Let me imagine, if I may, a deity which has produced itself from eternity; because production itself cannot be thought without diversity, so it must necessarily appear to itself as a second, which we recognize under the name of the Son.

This mitotic process of reproduction through self-division repeats itself once more until all three members of the holy trinity have come into appearance. Although this effectively closes the circle of the Christian godhead, creation does not stop there. It must continue further outward on its path of autopoetic expansion: " $\mathrm{Da}$ jedoch der Produktionstrieb immer fortging, so erschufen sie ein Viertes [...] Dieses war nun Lucifer, welchem von nun an die ganze Schöpfungskraft übertragen war" (FA 1.14:383; Because the productive drive must always push onwards, so a fourth was created [...] And this was Lucifer, to whom the entire force of creation was thus conferred). Even the godhead must submit to the demands of the productive drive, which becomes bound to the negativity of Lucifer while passing from the infinite into the finite.

The connection that Goethe draws here between the bifurcations of the productive drive and Lucifer's reign over creation serves to put an organic, productive spin on the idea, initially outlined by Spinoza, that negation, as a cosmic-ontological force, possesses some form of figurative functionality in the universe: "Since figure is nothing but determination, and determination is negation, figure can be nothing other than negation." ${ }^{3}$ While Spinoza intended to explain why negation could never actually exist in a universe that was not finite, but composed of a single infinite all-encompassing substance, Goethe embraced this suggested view of negativity as a means of understanding the "productive drive" underlying the complex activity of the organic world. ${ }^{4}$ This revisionist take on Spinozist negativity puts Goethe's thinking squarely in line with that of the twentieth-century physicist and philosopher of science, Erwin Schrödinger, while drawing further attention to the thermodynamic context of the critique of das Veloziferische. Schrödinger, who was not by chance an avid reader of both Goethe and Spinoza, famously made the case that biological organisms, while not exactly rooted in principles that are exogenous to the rest of the physical universe, possess astoundingly intricate ways of negotiating these principles in exchange with their surroundings. ${ }^{5}$ The second law of thermody- namics, for example, which states that entropy increases irreversibly over time, is never broken in the achievement of organic growth and reproduction. Instead, entropy is simply negotiated and redistributed in highly diffuse ways across an organism's milieu. Disorder and death are deferred in complex ways, but never overcome, a characteristic of organic life that Schrödinger dubs negative entropy. ${ }^{6}$ This unique type of negativity, which is in a certain sense the negation of negation itself, of the Mephistophelean tendency towards death and chaos, serves to remind the reader of what is at stake in Goethe's diagnosis of the modern world as veloziferisch. The bifurcations of the productive drive can only function so quickly, otherwise they become chaotic and destructive, impossible to subdue in their velocity.

Goethe was keen to articulate an alternative form of negation which, like Schrödinger's negative entropy, would play a figurative role, moving at speeds capable of guiding organic matter along on its path of autopoietic formation. A prominent instance of this type of figurative negativity can be found in Goethe's 1803 poem "Weltseele," or "World-Soul," titled after the philosopher F. W. J. Schelling's 1798 essay of the same name. ${ }^{7}$ In this cosmic paean composed of nine rhymed quatrains, Goethe lauds the dialectical dynamism of Schelling's vision of the cosmos as a complex organism. The poem presents the reader with a celebration of natural motion, beginning with an energetic urge for the "world soul" to expand itself into space and to fill the empty cosmos with its life force. "Verteilet euch" (disperse), the poet exclaims to the dynamo, urging it onward and outward. Already in the first line the organism is referred to in the plural, and the world soul is encouraged along in its mitotic, expansive bifurcations. "Begeistert reißt euch durch die nächsten Zonen / Ins All und füllt es aus!" (FA 1.2:491; Rip yourselves enraptured through the next zones / into the All and fill it out!). In the third stanza, the poem encourages racing, powerful (gewaltig) comets onward in their journey through the heavens (FA 1.2:492). In the fourth, the world soul shows a keenness to exhibit its capacity for figurative negation, "greift rasch nach ungeformten Erden" (FA 1.2:492; grasp rapidly towards unformed earth) with the creative force of youth. In the fifth stanza, however, the cosmic force begins to slowly retreat from its previous expansive, outward-moving impulse. Yet here it nonetheless maintains its function as determinatively figurative, providing a natural grapheme of sorts by pre-scribing (vorschreiben) solid, recognizable 
form to piles of previously nondescript stone found in cavernous vaults (FA 1.2:492). At the end of the poem, however, the world-soul does eventually run out of steam. A previously inexhaustible, boundless striving (unbegrenztes Streben) is dissolved in a blissful exchange of glances with the cosmos, receiving back the life it had given. Despite this entropic ending, however, there is hope that other divisions might later occur in this once open, expansive system: "Kein Wesen kann zu Nichts zerfallen" (No being can fully disintegrate into nothing), Goethe reminds us at the beginning of "Vermächtnis" (FA 1.2:685-86; Legacy), a poem quoted by Schrödinger at the beginning of one of his lectures; life itself is the law and treasure "[a]us welchen sich das All geschmückt" (from which the universe adorns itself). ${ }^{8}$

While Goethe's "Weltseele" serves to highlight the productive, even vibrant role assumed by negation in nature and natural figuration, the poem also provides one of numerous examples in Goethe's oeuvre of the celebration of speed, rather than its critique. Particularly from Goethe's early Sturm und Drang years, one finds a number of texts lauding the excitement of a quickening pace of life. In a 1774 poem titled "An Schwager Kronos" (To Coachman Chronos) Goethe seeks to recreate the breathtaking excitement of a late-night carriage ride through uneven, unrhymed verse. "Spude dich Kronos" (Spurs to, Kronos), the first stanza begins, "Fort den rasselnden Trott" (FA 1.1:201-2; onward the racing trot!). The opening stanza continues in a hurried pace rushing downhill and "[r]asch in's Leben hinein" (FA 1.1:202; swiftly down towards life). The poet gives an impressionistic account of sticks, stones, and roots flying past him at the coach's breakneck speed. In the next stanza, which describes the more belabored (mühsam) effort of the coach pulling back uphill after racing downwards, the poet implores the coachman not to grow sluggish (träge) urging him "strebend und hoffend" (striving and hoping), onward and upward (FA 1.1:202). In another energetic poem, "Dauer im Wechsel" (Constancy in Change), Goethe references the pace of organic growth and change marked by the seasons as a means of urging his readers to hurry and take advantage of nature's offerings: "willst du nach den Früchten greifen, / Eilig nimm dein Teil davon! / Diese fangen an zu reifen / und die andern keimen schon" (FA 1.2:493; so you want to reach for the fruit / Well, take your share of it! / These are beginning to ripen / and the others are already shooting up).

\section{Velocity in the Age of Machinery}

While these passages serve to show that it is not velocity per se that is the object of critique for Goethe in his diagnosis of modernity as veloziferisch, it is clear that he believes a turning point has been reached in the pace of life by the time he creates the term in the 1820s. Modernity has by this time accelerated, in Goethe's view, in a manner that is particularly detrimental to reflection and organic growth. Life and thought, when dominated by ever speedier systems of communication and transportation, become disfigured. In a letter to his friend, the composer Carl Friedrich Zelter, Goethe describes his distaste for what he sees as the senseless chase after wealth (Reichtum) and speed (Schnelligkeit) that is visible all around him, especially in large cities like Berlin. He cites the railroad, express mail, the steam ship, and quickened communication networks as symptoms of this veloziferisch tendency. ${ }^{9}$ With these early signs of modernity and industry, the negating, teuflisch aspect of das Veloziferische functions to deform. Of course, Goethe was not alone in his critical attitude. In the same year as the term veloziferisch went into print, the British essayist and historian Thomas Carlyle famously described this set of developments as a "mechanical age" and "the Age of Machinery," describing this new period as an age "which, with its whole undivided might, forwards, teaches and practises the great art of adapting means to ends." ${ }^{10}$ Whereas a number of thinkers such as the French philosopher Henri de Saint-Simon and his followers, or Bertrand Russel in his 1932 essay "In Praise of Idleness," held relatively optimistic views of the benefits afforded to humankind by industry, Goethe, like Carlyle and others, was much more skeptical of the benefits afforded by this "Age of Machinery." 11

The mechanical nature of modernity emphasized in Carlyle's essay, in fact, may prove useful for achieving an understanding of veloziferisch as a limit point of sorts for modernity. Das Veloziferische, as has been noted, suggests a transgression. It marks the limit beyond which machinic motion simply outpaces that of Bildung and of the organic. Das Veloziferische serves to uncover, for Goethe, a dangerous separation that has taken place between the mechanical and the organic, a traumatic rupture lying at the very heart of modernity's self-image. ${ }^{12}$ The 
term enacts the rapid speed at which the technicity of figuration-encompassing, poetry, thought, and lifeloses control, passing over into the totalizing, hegemonic technologos of a modernity careening, threating to fly off the rails. ${ }^{13}$ With this in mind, it is no surprise that Goethe's Faust is commonly read as a tragedy allegorizing the rapid pace of modernity. In fact, the pact signed by Faust even requires a uniquely symbolic sacrifice of the organic for the sake of veloziferisch mechanicityFaust must sign in blood, "ein ganz besonderer Saft" (FA 1.7:77; a very special sap) of organic life. ${ }^{14}$

\section{Restless Modernity}

With this velocital feature of the Faustian bargain in mind, it is easy to see how Goethe's term has caught the critical imaginations of sociologists, historians, and critical theorists who are interested in studying the accelerated pace of modernity and its effect on institutions, individuals, and the natural world. The writings of Hartmut Rosa, a political theorist and sociologist who has spent much of his life studying the political, social, and existential implications of these phenomena of acceleration, are filled with references to das Veloziferische, in addition to reflections on numerous writings by Goethe. In his 2005 Habilitationsschrift, Rosa suggests that Goethe's invention of the term veloziferisch presents an early indication of the appearance of a new modern ideal for life itself-that of "the full life" (das erfüllte Leben). ${ }^{15}$ The full life is one in which a person must tirelessly take advantage of every opportunity available, without a moment's pause. Any respite would mean falling behind, missing out on an important opportunity. Goethe's critical stance taken towards this veloziferisch way of life is so integral to Rosa's critical theory of speed that his English translator, Jonathan Trejo-Mathys, begins his introduction with a passage from the posthumously published Maxims and Reflections in which Goethe decries the "lack of th[e] indispensable requirement of symmetry" in modern life, explaining that "this is a mischief which will often occur in modern times. For who will be able to come up to the claims of an age so full and intense as this," he continues, "and one too that moves so rapidly?" 16 This lack of symmetry and the overhasty pace of life, for Rosa, finds its clearest, fullest, and earliest expression in Goethe's Faust, whose title character's "patience-cursing restlessness" reveals some of the most destructive consequences of the manic attempt at living an "erfülltes Leben," a full life. ${ }^{17}$
It is patience, Geduld, that Faust curses above all in his study with Mephistopheles (FA 1.7:73), and his lines accompanying the blood-pact that seals his fate suggest an impatient, manic desire for this new existential ideal: "Stürzen wir uns in das Rauschen der Zeit / Ins Rollen der Begebenheit [. . .] / Nur rastlos betätigt sich der Mann" (FA 1.7:78; Let us plunge into time's whirl that dazes my sense / Into the torrent of events [...] / For restless activity proves a man). ${ }^{18}$ The reply he receives from Mephisto, "[e]uch ist kein Maß und Ziel gesetzt" (FA 1.7:78; you truly know neither measure nor end), seems not just directed at Faust. With these blunt words, it would appear that Goethe wishes to implicate all of modernity in Faust's fate. And of course, it is not just in Faust that one finds such warnings against impatient thinking and hasty action. In his 1793 essay on scientific method, "Der Versuch als Vermittler von Objekt und Subject" (The Experiment as Mediator between Object and Subject), Goethe implores the natural observer " $[\mathrm{s}]$ ich vor jeder Übereilung [zu] hüten" (FA 1.25:27; [to] protect herself against all rushing), also warning against the temptation to hastily decide in favor of a certain scientific theory or in support of a predetermined idea while examining the results of a particular scientific study (FA 1.25:30).

\section{Conclusion: On Steuerung}

As critical as Goethe may be of impatience, Ungeduld, and of Übereilung, the restless haste of modern life signified by das Veloziferische, we must nevertheless be careful not to group his attitude together with those of thinkers who are unconditionally, often uncritically, in favor of the slow. Unlike Francis Bacon, who in his Novum Organum rather comically suggests outfitting the human intellect with lead weights rather than with wings in order to slow it down, Goethe's understanding of a healthy speed for thought is integrally tied to the plastic pace of figuration in organic growth. ${ }^{19}$ The veloziferisch does serve as a warning for Goethe's readers that an upper speed limit has been reached, a point beyond which the mechanical outpaces the organic and destroys it. However, this does not mean that there are no lower limits for motion, below which such restrictions on speed may be equally stifling and destructive for the work of Bildung. For example, in his closing monologue, the court poet Torquato Tasso in Goethe's 1790 play of the same name decries the inertial lifelessness of courtly life, contrasting it with 
the mighty power of a storm that is brewing along the coast. The work of figuration Tasso sought in poetry, and indeed in love, is stifled by the slowness and fixity of life at court. His only recourse is to evoke the dynamic, threatening force of a natural storm, whose motions will ultimately prove more powerful than any social or political figuration (FA 1.5:833).

While drawing a vividly slow-moving counterpoint to the techno-accelerationist allegory one finds in the Faust myth, Tasso's closing monologue also introduces an important figure of thought that may prove useful for understanding how Goethe understood both the upper and lower limits of the speed of figuration. In resignation, Tasso cries, "Zerbrochen ist das Steuer und es kracht / Das Schiff an allen Seiten. Berstend reißt / Der Boden unter meinen Füßen auf!" (FA 1.5:834; The rudder is broken / And the ship is creaking on all sides. / The floor beneath my feet is being torn apart!). In the absence of steering, the ship is headed for sure destruction. Yet with the restoration of Steuerung, political and cultural steering mechanisms for the maintenance of control, the veloziferisch tendency of modernity may yet be reined in. A controlled, pleasurable pace may be restored, while, perhaps more importantly, avoiding the catastrophic alternative - an impoverished, destructive life in which history is experienced as the incessant, accelerated "hurling of debris upon debris" before one's feet. ${ }^{20}$ 


\section{Notes}

${ }^{1}$ Manfred Osten, "Alles veloziferisch" oder Goethes Entdeckung der Langsamkeit (Göttingen: Wallstein Verlag, 2013).

2 See Daniel Kahnemann's best-selling book on "slow-thinking" for an example of this. Daniel Kahnemann, Thinking, Fast and Slow (New York: Farrar, Strauss and Giroux, 2011).

${ }^{3}$ See Spinoza, Spinoza Opera IV: Epistolae, ed. Carl Gebhardt (Heidelberg: Carl Winters, 1925), 240. "Quia ergo figura non aliud, quam determinatio, et determinatio negatio est; non poterit, ut dictum, aliud quid, quam negatio, esse." Translation by Edwin Curley. See Yitzhak Y. Melamed, "Omnis Determinatio Est Negatio:' Determination, Negation, and Self-Negation in Spinoza, Kant, and Hegel," in Spinoza and German Idealism, ed. Eckart Förster and Yhitzhak Y. Malamed (Cambridge: Cambridge UP, 2012), 176.

${ }^{4}$ See Melamed, “'Omnis Determinatio Est Negatio', 175-96.

${ }^{5}$ See "Chapter 1: The Classical Physicist's Approach to the Subject" in Erwin Schrödinger, What Is Life? (Cambridge: Cambridge UP, 2012), 3-18.

${ }^{6}$ See Schrödinger, What is Life?, 70.

${ }^{7}$ See Schelling, Von der Weltseele, eine Hypothese der höhern Physik zur Erklärung des allgemeinen Organismus, ed. Jörg Jantzen et al. (Stuttgart: Frommann-Holzboog, 2000).

${ }^{8}$ See Schrödinger, What is Life?, 19.

${ }^{9}$ See Osten, "Alles veloziferisch," 10.

${ }^{10}$ See Thomas Carlyle, "Signs of the Times," in A Carlyle Reader. Selections from the Writings of Thomas Carlyle, ed. G. B. Tennyson (Cambridge: Cambridge UP, 1969), 24. Goethe's concept of "world literature" was also developed during this time in his correspondence with Carlyle. See the lexicon entry on Weltliteratur for more on this.

${ }^{11}$ See Bertrand Russel, "In Praise of Idleness," in In Praise of Idleness: And Other Essays, (New York: Routledge, 2004), 1-15.

${ }^{12}$ See Bruno Latour, We Have Never Been Modern (Cambridge: Harvard UP, 2012).

${ }^{13}$ For more on this important historical and philosophical distinction between technique and technology, a term which, although coined by Harvard Botanist Jacob Bigelow in 1828, did not take on its more current usage until decades letter, see Leo Marx, "Technology: The Emergence of a Hazardous Concept," Technology and Culture 51, no. 3 (2010): 561-77.

${ }^{14}$ For more on this, see Helmut Müller-Sievers, "The Curse of Technics: A Gloss on the World-Curse in Goethe's Faust," MLN 131, no. 3 (2016): 656-61.

${ }^{15}$ See Hartmut Rosa, Beschleunigung: Die Veränderung der Zeitstrukturen in der Moderne (Frankfurt a.M.: Suhrkamp, 2017).

${ }^{16}$ See Jonathan Trejo-Mathys, "Translator's Introduction: Modernity and Time," in Hartmut Rosa, Social Acceleration: A New Theory of Modernity, trans. Jonathan Trejo-Mathys (New York: Columbia UP, 2013), xi.
${ }^{17}$ For more on Faust's "patience-cursing restlessness," see Rosa, Beschleunigung, 72.

${ }^{18}$ I have made use of Walter Kaufmann's translation here. See Goethe, Goethe's Faust, trans. Walter Kaufmann (New York: Anchor, 1961), 186-87.

${ }^{19}$ See Francis Bacon, The New Organon and Related Writings, ed. Fulton H. Anderson (New York: Liberal Arts Press, 1960), 98.

${ }^{20}$ This image has been lifted from Walter Benjamin's description of the angel of history. See Walter Benjamin, "Über den Begriff der Geschichte," in Illuminationen. Ausgewählte Schriften I(Frankfurt a.M.: Suhrkamp, 1977), 255.

\section{Related Entries in the GLPC}

Begriff (concept), Bestimmung (determination), Bildung (formation), Eile (hurry), Figur (figure), Gestalt/Gestalten (shape(s)), Luziferisch (luciferian), Negation (negation), Produktivität (productivity), Spinoza (spinoza), Steuerung (steering), Teufel/Teuflisch (devil/devilish), Übereile (overhaste), Weltliteratur (world Literature), Welt (world)

\section{Works Cited and Further Reading}

Bacon, Francis. The New Organon and Related Writings. Edited by Fulton H. Anderson. New York: Liberal Arts Press, 1960.

Benjamin, Walter. Gesammelte Schriften Edited by Rolf Tiedemann and Hermann Schweppenhäuser. 14 vols. Frankfurt a.M.: Suhrkamp, 1991.

Carlyle, Thomas. "Signs of the Times." In A Carlyle Reader. Selections from the Writings of Thomas Carlyle, edited by G. B. Tennyson, 31-54. Cambridge: Cambridge UP, 1969.

Geulen, Eva. Aus dem Leben der Form: Goethes Morphologie und die Nager. Berlin: August Verlag, 2016.

Goethe, Johann Wolfgang von. Goethe's Faust. Translated by Walter Kaufmann. New York: Anchor, 1961.

-. Sämtliche Werke, Briefe, Tagebücher und Gespräche. Edited by Hendrik Birus, Dieter Borchmeyer, Karl Eibl, et. al. 40 vols. Frankfurt a.M.: Deutscher Klassiker Verlag, 1987-2013. 
Kahnemann, Daniel. Thinking, Fast and Slow. New York: Farrar, Straus and Giroux, 2011.

Klausmeyer, Bryan. "Abschlussbewegungen: Goethe, Freud, and Spectral Forms of Life." Goethe Yearbook 26, no. 1 (2019): 163-78. https://doi.org/10.1353/ gyr.2019.0025.

Latour, Bruno. We Have Never Been Modern. Cambridge: Harvard UP, 2012.

Marx, Leo. "Technology: The Emergence of a Hazardous Concept." Technology and Culture 51, no. 3 (2010): 561-77. https://doi.org/10.1353/tech.2010.0009.

Melamed, Yitzhak Y. “' 'Omnis Determinatio Est Negatio': Determination, Negation, and Self-Negation in Spinoza, Kant, and Hegel." In Spinoza and German Idealism, edited by Eckart Förster and Yitzhak Y. Melamed, 175-96. Camrbdige: Cambridge UP, 2012.

Müller-Sievers, Helmut. "The Curse of Technics: A Gloss on the World-Curse in Goethe's Faust." $M L N$ 131, no. 3 (2016): 656-61. https://doi.org/10.1353/ mln.2016.0043.
Osten, Manfred. "Alles veloziferisch" oder Goethes Entdeckung der Langsamkeit. Göttingen: Wallstein Verlag, 2013.

Rosa, Hartmut. Beschleunigung: Die Veränderung der Zeitstrukturen in der Moderne. Frankfurt a.M.: Suhrkamp, 2017.

Russel, Bertrand. "In Praise of Idleness." In In Praise of Idleness: And Other Essays, 1-15. New York: Routledge, 2004.

Schelling, Friedrich Wilhelm Joseph von. Historisch-kritisch Ausgabe. Ed. Jörg Jantzen et al. 36 vols. Stuttgart: Frommann-Holzboog, 1976 - present.

Schrödinger, Erwin. What Is Life?: With Mind and Matter and Autobiographical Sketches. Cambridge: Cambridge UP, 2012.

Spinoza, Benedictus de. Spinoza Opera IV: Epistolae. Edited by Carl Gebhardt. Heidelberg: Carl Winters, 1925.

Trejo-Mathys, Jonathan. "Translator's Introduction: Modernity and Time." In Hartmut Rosa, Social Acceleration: A New Theory of Modernity. Translated by Jonathan Trejo-Mathys, xi-xxxi. New York: Columbia UP, 2013. 